\title{
Limnophase versus potamophase: how hydrological connectivity affects the zooplankton community in an oxbow lake (Vistula River, Poland)
}

\author{
Paweł Napiórkowski ${ }^{1 *}$ and Teresa Napiórkowska ${ }^{2}$ \\ 1 Department of Hydrobiology, Faculty of Biology and Environmental Protection, Nicolaus Copernicus University in Toruń, \\ Lwowska 1, 87-100 Toruń, Poland \\ 2 Department of Invertebrate Zoology, Faculty of Biology and Environmental Protection, Nicolaus Copernicus University in Toruń, \\ Lwowska 1, 87-100 Toruń, Poland
}

Received 16 November 2016; Accepted 12 January 2017

\begin{abstract}
The functioning of oxbow lakes depends primarily on the succession of two phases: potamophase (when water from the river flows into the lake) and limnophase (when water remains in the riverbed, ensuring stability in the lake). Hydrologic conditions in the river determine whether oxbows are isolated or connected with the river. They also determine the time and duration of both phases. The studied oxbow lake, located in the floodplain of the lower Vistula, was created as the result of river regulation in the 19th century. Observations were conducted during growing seasons in 2006, 2007, 2008 and 2013, during limnophase and potamophase. The study was aimed at evaluating the impact of changes in the river level on the oxbow lake. Potamophase brought greater zooplankton diversity. We recorded a higher number of species and a higher Shannon diversity index $\left(H^{\prime}\right)$. During limnophase, higher water temperature led to greater zooplankton density. However, its diversity decreased. In recent years, probably due to climate change, the amount of precipitation has decreased. As a result, water levels in rivers are lower and potamophase is rare, while periods of isolation are longer. Low water levels in oxbows increase their primary productivity and decrease zooplankton biodiversity.
\end{abstract}

Key words: Floodplain / River / Zooplankton / Diversity / Hydrology / Flood-pulse

\section{Introduction}

Whether natural or artificial (created through river regulation), oxbow lakes constitute an important element of river valleys (Redford and Richter, 1999; Funk et al., 2009; Tockner et al., 2009).

They play an important role in water retention, protect the river from excessive inflow of nutrients from the land and ensure biodiversity of the entire river ecosystem (Shiel et al., 1998; Hillbricht-Ilkowska, 1999; Lake and Bond, 2007; Paira and Drago, 2007). The functioning of oxbow lakes depends on seasonal flooding of the river valley according to the river flood-pulse concept (Junk et al., 1989). As a result of flood-pulse dynamics, structural components of the system can be connected. This facilitates the exchange of water, nutrients and living organisms (biota) between parts of riverine corridors

\footnotetext{
*Corresponding author: pnapiork@umk.pl
}

(Amorus and Bornette, 2002; Anderson and Bonecker, 2004; de Paggi and Paggi, 2008).

Basically, flood pulsing leads to the succession of two phases in the life of oxbow lakes: limnophase and potamophase (Neiff, 1996), i.e. the isolation or connection of the oxbow with the river. During limnophase (isolation) relatively stable conditions promote the growth of macrophytes and many algal groups (Dembowska and Napiórkowski, 2012; Reckendorfer et al., 2013). Due to a shallow depth and a well-developed macrophyte community, oxbow lakes provide microhabitats offering conditions suitable for the development of littoral, pelagic and peryphytic fauna (Thomaz et al., 2007; Wojciechowska et al., 2007; Joniak and KuczyńskaKippen, 2016). In this phase, they are similar to shallow macrophytic lakes (Scheffer and Jeppesen, 1998; Mihaljevič et al., 2009) and can develop distinctly unique features. The density of zooplankton and the number of crustacean species increase (Baranyi et al., 2002; de Paggi and Paggi, 2008). 
Periods of stability are interrupted (usually with great regularity) by periods of flooding (Junk et al., 1989; Wojciechowska et al., 2007; Chaparro et al., 2015). The supply of water from the river raises the water level (WL) in oxbow lakes. Living organisms are washed away and the sediments accumulated during limnophase are leached. Water transparency decreases drastically because river water carries huge amounts of suspended matter. This has a negative effect on macrophytes, which die due to a lack of sunlight. Eventually, small organisms brought by the river (diatoms and rotifers) begin to dominate (Riss and Biggs, 2003; Mihaljevič et al., 2009; Napiórkowski, 2009; Dembowska, 2015a; Dembowska and Napiórkowski, 2015)

This water exchange triggers the recovery of the biocenosis; the nature and scope of the shifts depend on the intensity of flooding (Chaparro et al., 2011; Reckendorfer et al., 2013). Initially, organisms brought by the river play a key role. Potamophase is again followed by limnophase, which brings stability. At a later stage, the composition and growth rate of organisms depend on the type of lake and its primary productivity. Observations indicate that the biocenosis of oxbow lakes changes with each limnophase and potamophase. The number of successive phases is strictly connected with hydrologic conditions in the river basin (precipitation, thaw) (Dembowska and Napiórkowski, 2012).

The importance of planktonic organisms for oxbow lakes has been described by many authors, including Keckeis et al. (2003), Gumiri et al. (2005), Napiórkowski (2009), Furst et al. (2014), Dembowska and Napiórkowski (2015), Kobayashi et al. (2015), and Krztoń et al. (2017).

Anderson and Bonecker (2004) as well as Schöll (2009) pointed out that planktonic communities in oxbow lakes are determined primarily by two features: (1) whether they are connected or not to the river and (2) whether water inflow causes any disturbances.

This study was aimed at evaluating the effect of changes in the river level on an oxbow lake. Hydrologic conditions of the river determine whether oxbow lakes are isolated or connected to the river. They also determine the time and duration of both phases (Neiff, 1996; de Paggi and Paggi, 2008; Paidere, 2009).

We anticipated a greater zooplankton biodiversity during potamophase (water from the river can introduce species that are not found in oxbow lakes at a low WL). The river can also introduce different types of food, thus indirectly affecting the structure of zooplankton.

We also assumed that limnophase will be characterized by greater zooplankton density. In small and fertile lakes, the contribution of internal supply may increase (Carvalho et al., 2001; Thomaz et al., 2007).

It is therefore possible that hydrologic conditions can directly influence the structure of zooplankton: stagnation brings better conditions for crustaceans, and flooding, for rotifers.

At low or absent hydrological connectivity, oxbow lakes have characteristics of shallow eutrophic lakes, exhibiting a clear water state with macrophyte dominance, or a turbid state with phytoplankton dominance caused by the input of nutrients (alternative stable state hypothesis Scheffer et al., 1993; Reckendorfer et al., 2013).

In the studied lake, periods of macrophyte dominance were followed by periods of phytoplankton dominance even during limnophase. Macrophytes are known to develop more rapidly during limnophase, creating many ecological niches. This, in turn, can promote the growth of zooplankton, thus increasing biodiversity.

In recent years, probably due to climate change, the amount of precipitation has decreased. As a result, WLs in rivers are low and potamophase is rare. The question then arises: will changes of this kind threaten biodiversity in oxbow lakes and river valleys?

\section{Materials and methods}

\section{Study site}

The study was conducted in an oxbow lake in the lower Vistula valley. The Vistula is the longest river in Poland $(1068 \mathrm{~km})$ and has the second highest flow rate $\left(\mathrm{Q}, 1050 \mathrm{~m}^{3} \cdot \mathrm{s}^{-1}\right)$ after the Neva in the catchment area of the Baltic Sea. Over almost its entire length, it is a typical lowland river. In its lower course (between 718 and 1068 $\mathrm{km}$ - the mouth) it was regulated in the 19th century.

Despite human interference (changing the river's flow) and advancing degradation, the River and the Valley represent an extremely valuable natural environment (Kentzer et al., 2010). The first floodplain terrace has a number of oxbow lakes that are the remnants of the backwaters of the river and are periodically flooded (during major floods only). The study was conducted on a floodplain lake created after the flood embankments had been constructed during river regulation at the beginning of the 19th century (Makowski, 1998). The studied oxbow lake (Fig. 1) is situated in the valley of the Lower Vistula, within the city of Torun, at $738 \mathrm{~km}$ of the river's course $\left(53^{\circ} 00^{\prime} \mathrm{N} ; 18^{\circ} 33^{\prime} \mathrm{E}\right)$. This water body lake developed as a result of Vistula River regulation. It is relatively shallow, young and usually connected to the Vistula River (with the average $\mathrm{WL}$ in the river). In the oxbow lake, the following

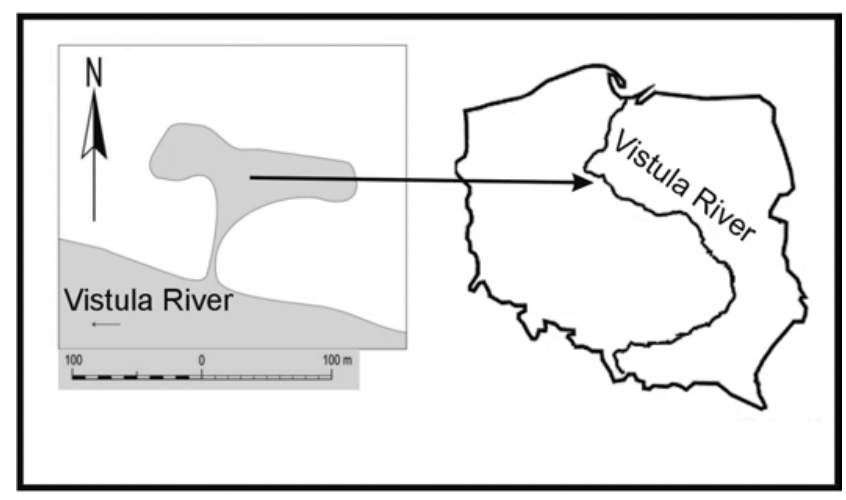

Fig. 1. Map of investigated area. 


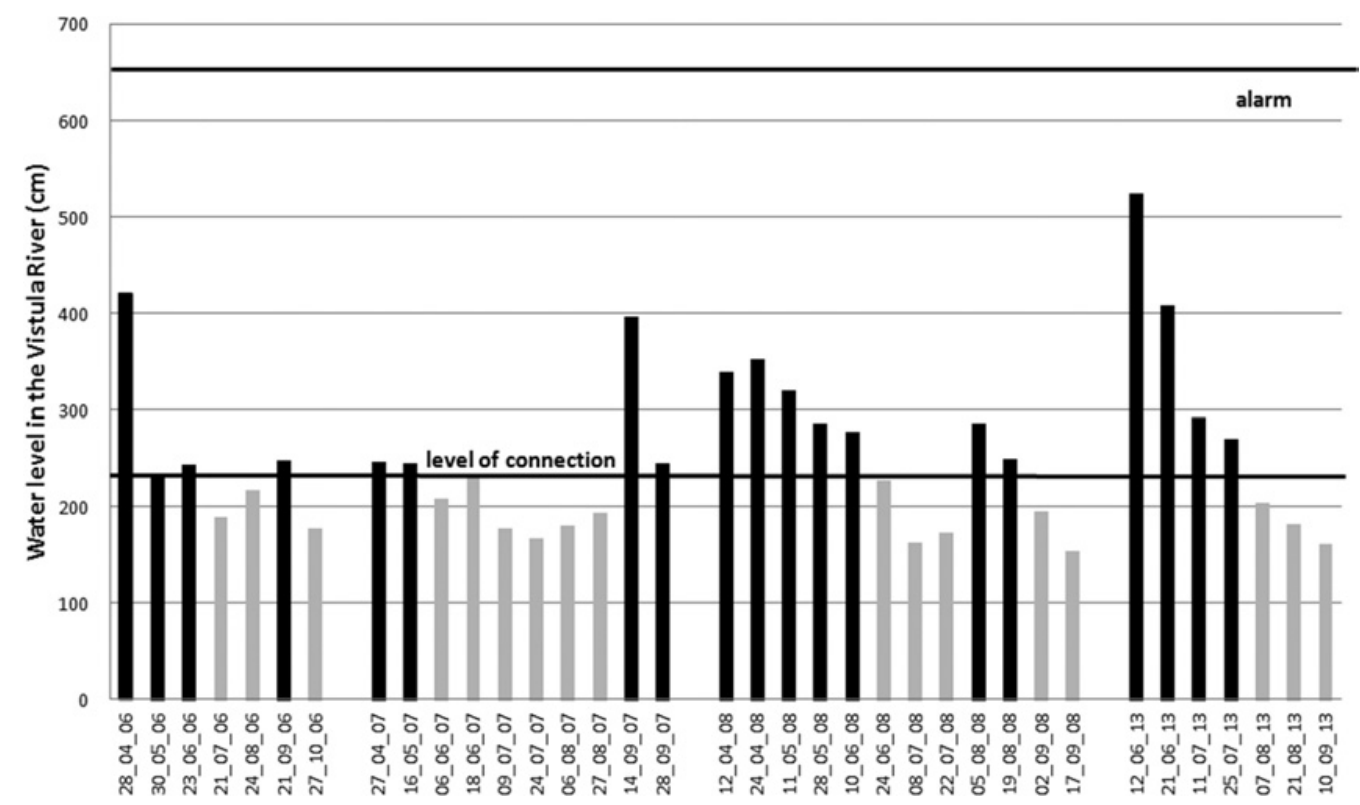

Fig. 2. Water level (WL, cm) in the Vistula River (black bars - potamophase, gray bars - limnophase).

species of macrophytes occur: common hornwort (Ceratophyllum demersum L.), arrowhead (Sagittaria sagittifolia L.), which grow on the shores of the oxbow lake, but when the WL is very low, it forms peculiar islands in the middle of the oxbow lake, Canadian waterweed (Elodea canadiensis Michx.), pondweed species (Potamogeton sp.) and water milfoil sp. (Myriophyllum sp.). The morphometric characteristics of the floodplain lake are: surface area 1.0 ha, maximum length $160 \mathrm{~m}$, maximum width $100 \mathrm{~m}$ and degree of connection with the Vistula River from 0 to $30 \mathrm{~m}$. The maximum depth depends on the WL in the river (from 60 to $160 \mathrm{~cm}$ ) (Dembowska and Napiórkowski, 2015).

The value of $P_{\text {tot }}$ in summer in 2008 amounted to $0.36 \mathrm{mg} . \mathrm{L}^{-1}$ and the concentration of mineral forms of nitrogen and phosphorus amounted to $0.208 \mathrm{mg} . \mathrm{L}^{-1}$ $\left(\mathrm{N}-\mathrm{NO}_{3}\right)$ and $0.067 \mathrm{mg} . \mathrm{L}^{-1}\left(\mathrm{P}-\mathrm{PO}_{4}\right)$ (Dembowska and Napiórkowski, 2015).

\section{Methods}

Water samples were collected twice a month between April and September, 2006, 2007, 2008 and 2013. All zooplankton samples were collected at a depth of ca. $0.5 \mathrm{~m}$ in the central part of the lake with a $1 \mathrm{~L}$ Patalas sampler. Water was filtered through a plankton net; mesh size $25 \mu \mathrm{m}$. In order to obtain one sample of zooplankton, $10 \mathrm{~L}$ of water were filtered. All zooplankton samples were preserved in Lugol's solution (Nogrady, et al., 1993; Harris et al., 2000). The identification of zooplankton was performed with the use of a light microscope Nikon Alphaphot-2 as well as a Panasonic camera and MultiScan computer software for image analysis.
The taxonomical identification of zooplankton was made according to the commonly available studies and keys (Flössner, 1972; Kiefer, 1978; Nogrady et al., 1993; Einsle, 1996; Smirnov, 1996; Radwan et al., 2004; Rybak and Błędzki, 2010).

To characterize the density-dominance relationship, the Shannon-Weaver diversity index $\left(H^{\prime}\right)$ was used.

The collection of samples was measured along with the physical and chemical parameters of water, such as: Secchi disk visibility $(\mathrm{SD}, \mathrm{m})$, temperature (WT, $\left.{ }^{\circ} \mathrm{C}\right)$, oxygen concentration (DO, mg. $\mathrm{L}^{-1}$ ), saturation (DO sat., \%), conductivity $\left(\mathrm{EC}, \mu \mathrm{S} . \mathrm{cm}^{-1}\right)$ and $\mathrm{pH}$. Measurements of physico-chemical parameters were performed by Multi 3430SET F WTW field probes. Data on the WL $(\mathrm{cm})$ of the Vistula River in Torun were obtained from the Meteorological and Hydrological Institute - the Regional Hydrological and Meteorological Station in Toruń, Poland.

A total of 36 observations were conducted, 19 during potamophase (when the oxbow lake was connected with the river) and 17 during limnophase (when the oxbow lake was isolated from the river) (Fig. 2). We assumed that limnophase will occur when the WL in the river is lower than $231 \mathrm{~cm}$ (low water level), while potamophase, when the WL is higher than $231 \mathrm{~cm}$ (medium and high WL according to The Institute of Meteorology and Water Management in Poland - IMGW).

A nonparametric Spearman rank $\mathrm{R}$ coefficient (IBM SPSS (IBM Corp. Released, 2012)) was applied to analyze the relationships between the number of species, the total number of zooplankton, $H^{\prime}$ and the environmental factors.

A canonical correspondence analysis (CCA) was performed using MVSP 3.22 software to show the relations between zooplankton and physico-chemical 
Table 1. Physicochemical parameters in the oxbow lake and water level of the Vistula River in Torun during potamophase and limnophase.

\begin{tabular}{lcccr}
\hline & \multicolumn{2}{c}{ Potamophase } & & Limnophase \\
\cline { 2 - 4 } & Mean & Range & Mean & 188 \\
\hline WL $(\mathrm{cm})$ & 310 & $234-525$ & 20.3 & $154-230$ \\
WT $\left({ }^{\circ} \mathrm{C}\right)$ & 17.9 & $9.0-23.8$ & 0.50 & $11.2-23.6$ \\
SD $(\mathrm{m})$ & 0.58 & $0.50-1.20$ & 8.5 & $0.30-1.05$ \\
DO $\left(\mathrm{mg} . \mathrm{L}^{-1}\right)$ & 7.8 & $3.7-14.6$ & 8.6 & $4.0-14.6$ \\
pH & 8.4 & $7.8-8.9$ & 662 & $7.7-10.5$ \\
EC $(\mu \mathrm{S})$ & 579 & $413-920$ & $512-946$ \\
\hline
\end{tabular}

water level $(\mathrm{WL}, \mathrm{cm})$, temperature $\left(\mathrm{WT},{ }^{\circ} \mathrm{C}\right)$, Secchi disk visibility $(\mathrm{SD}, \mathrm{m})$, oxygen concentration $\left(\mathrm{DO}, \mathrm{mg} \cdot \mathrm{L}^{-1}\right)$, conductivity $\left(\mathrm{EC}, \mu \mathrm{S} . \mathrm{cm}^{-1}\right)$.

Table 2. Total number of species and dominants in the zooplankton community during potamophase and limnophase.

\begin{tabular}{|c|c|c|}
\hline & Potamophase & Limnophase \\
\hline Rotifera & 50 & 41 \\
\hline Crustacea & 13 & 15 \\
\hline SUM & 63 & 56 \\
\hline \multirow[t]{4}{*}{ Dominant species and percent of domination } & Keratella cochlearis $29 \%$ & Keratella tecta $42 \%$ \\
\hline & Polyarthra longiremis $15 \%$ & Brachionus angularis $12 \%$ \\
\hline & Keratella tecta $14 \%$ & Filinia longiseta $12 \%$ \\
\hline & Brachionus calyciflorus $8 \%$ & Polyarthra longiremis $11 \%$ \\
\hline \multirow{2}{*}{ Species typical for one phase } & $13 *$ & $4 *$ \\
\hline & $4 * *$ & $6 * *$ \\
\hline
\end{tabular}

*Rotifera, $* *$ Crustacea.

parameters at the investigated floodplain lake (Kovach, 2010).

\section{Results}

\section{Physical and chemical parameters}

During the research, water levels in the Vistula ranged from $154 \mathrm{~cm}$ (September 17, 2008) to $525 \mathrm{~cm}$ (June 12, 2013) (average: $249 \mathrm{~cm}$ ) (Table 1).

The average water temperature in the oxbow was $19.1^{\circ} \mathrm{C}$. In potamophase, the average temperature was $17.9^{\circ} \mathrm{C}$ and in limnophase, $20.3^{\circ} \mathrm{C}$ (Table 1 ).

The average water transparency was $54 \mathrm{~cm}$ and was slightly higher during potamophase (Table 1).

The average oxygen concentration was $8.15 \mathrm{mg} . \mathrm{L}^{-1}$ and was higher in limnophase (Table 1).

The average water $\mathrm{pH}$ was 8.5 and was similar during the two phases.

The average electrolytic conductivity was $620 \mu \mathrm{S} . \mathrm{cm}^{-1}$ and was higher during limnophase (Table 1).

\section{Zooplankton}

In total, 73 species of zooplankton were identified during the investigations, including 54 species of rotifers $(74 \%)$ and 19 species of crustaceans (26\%). More zooplankton species were recorded during potamophase
(63 species) than during limnophase (56 species). A higher number of rotifer species determined the number of zooplankton species in potamophase. During limnophase, a lower number of rotifer species and a higher number of crustacean species were recorded (Table 2). We noted 17 species specific for potamophase (13 rotifer species and 4 crustacean species) and only 10 species specific for limnophase (4 rotifer species and 6 crustacean species) (Table 2).

During potamophase, the diversity index $\left(H^{\prime}\right)$ was higher (Table 3). The average number of species in a water sample was also slightly higher.

The average zooplankton density was 2092 ind. $\mathrm{L}^{-1}$. The average zooplankton density during limnophase was more than twice as high as during potamophase. Similarly, rotifer density was more than twice as high and crustacean zooplankton density three times as high as during potamophase (Table 3).

Additionally, the number of dominant species and larval forms of copepoda was higher than during potamophase. Only Keratella cochlearis was more numerous during potamophase (Table 3).

During limnophase, rotifer species Keratella tecta, Brachionus angularis and Filinia longiseta were dominant among zooplankton; larval forms of copepoda (nauplii) and copepodites, as well as Bosmina longirostris, among crustaceans.

During potamophase, $K$. cochlearis, Polyarthra longiremis and $K$. tecta were dominant among rotifers. Bosmina longirostris, Diaphanosoma brachyurum and 
Table 3. Diversity $\left(H^{\prime}\right)$, number of zooplankton species, zooplankton density, density of dominant species during potamophase and limnophase.

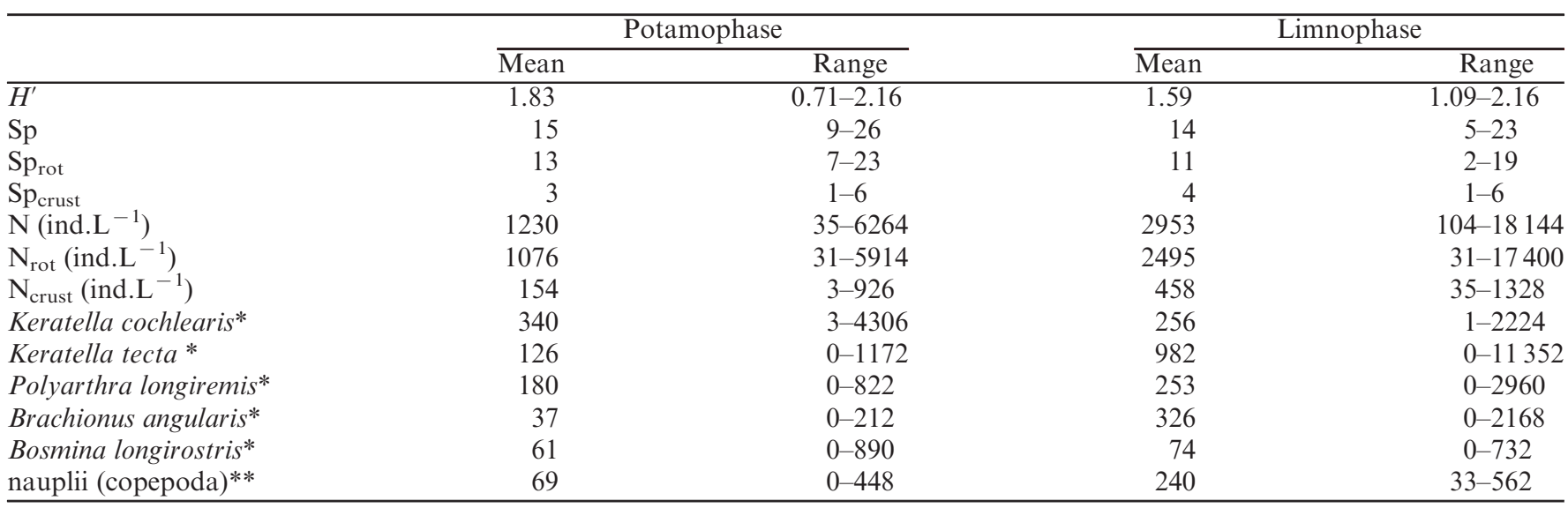

Shannon-Weaver diversity index $\left(H^{\prime}\right), \mathrm{Sp}-$ mean number of species, $\mathrm{Sp}$ rot - mean number of rotifers species, $\mathrm{Sp}_{\text {crust }}-\mathrm{mean}_{\mathrm{umber}}$ nu crustacean species, $\mathrm{N}$ - number zooplankton (ind. $\mathrm{L}^{-1}$ ), $\mathrm{N}_{\text {rot }}-$ number of rotifers, $\mathrm{N}_{\text {crust }}-$ number of crustacean.

*Number of dominant species of zooplankton (ind. $\mathrm{L}^{-1}$ ).

**Number of nauplii (larval stage of copepods) (ind. $\mathrm{L}^{-1}$ ).

Table 4. Nonparametric Spearman rank $\mathrm{R}$ coefficient for parameters of the floodplain lake.

\begin{tabular}{llcc}
\hline & WL & WT & DO \\
\hline $\mathrm{Sp}_{\text {rot }}$ & 0.113 & $-0.409^{*}$ & -0.247 \\
$\mathrm{Sp}_{\text {crust }}$ & $-0.373^{*}$ & $0.566^{*}$ & -0.156 \\
$\mathrm{Sp}$ & -0.033 & -0.141 & -0.204 \\
$\mathrm{~N}_{\text {rot }}$ & -0.188 & -0.045 & $0.372^{*}$ \\
$\mathrm{~N}_{\text {crust }}$ & $-0.585^{*}$ & $0.374^{*}$ & 0.093 \\
$\mathrm{~N}$ & -0.287 & 0.059 & 0.332 \\
$H^{\prime}$ & 0.293 & -0.093 & -0.159 \\
\hline
\end{tabular}

Water level (WL, cm), temperature (WT, $\left.{ }^{\circ} \mathrm{C}\right)$, oxygen concentration (DO, mg. $\mathrm{L}^{-1}$ ), Spec - mean number of species, $\mathrm{Spec}_{\text {rot }}$ - mean number of rotifers species, $\mathrm{Spec}_{\text {crust }}$ - mean number of crustacean species, $\mathrm{N}$ - number zooplankton (ind. $\mathrm{L}^{-1}$ ), $\mathrm{N}_{\text {rot }}-$ number of rotifers (ind. $\mathrm{L}^{-1}$ ), $\mathrm{N}_{\text {crust }}$ - number of crustacean (ind. $\mathrm{L}^{-1}$ ), Shannon-Weaver diversity index $\left(H^{\prime}\right)$. $* P \leq 0.05$.

larval forms of copepods were dominant among crustaceans.

The results indicate weak but statistically significant correlations: between water temperature and the number of species of crustacean zooplankton $(r=0.566 ; P \leq 0.05)$ and between water temperature and the density of crustacean zooplankton $(r=0.374 ; P \leq 0.05)$. WL in the river was negatively correlated with the number of species of crustacean zooplankton $(r=-0.373 ; P \leq 0.05)$ and with the density of crustacean zooplankton $(r=-0.585$; $P \leq 0.05)$. We also noted a negative correlation between water temperature and the number of rotifer species $(r=-0.409 ; P \leq 0.05)$, and a positive correlation between oxygen concentration and the density of rotifers $(r=0.372$; $P \leq 0.05$ ) (Table 4).

CCA analysis indicates that the density and number of species of crustaceans as well as the number of larval forms of Copepoda depend on temperature. Higher temperature during limnophase can promote the growth of crustacean zooplankton. The species diversity index $\left(H^{\prime}\right)$, the number of species and density of rotifers, as well as the total density of zooplankton were connected with a rising WL, which could be observed during potamophase.

\section{Discussion}

Oxbow lakes depend on cyclical flooding of the river valley according to the flood-pulse concept (Junk, et al., 1989). Flood-pulse dynamics determine the biocenosis and environmental conditions in these lakes (Amorus and Bornette, 2002).

Commonly, irregular water inflow from the river destabilizes conditions in oxbow lakes, affecting water transparency, water temperature and macrophyte growth. These changes have an impact on the planktonic population: phytoplankton is more abundant and diverse in lakes connected to the river than in lakes isolated from the river (Dembowska and Napiórkowski, 2015; Dembowska, 2015b). Water supply from the river should inhibit macrophyte growth and increase phytoplankton biomass (Joniak and Kuczyńska-Kippen, 2016). It should also provide nutrients and intensify nutrient release from the bottom sediments (Hein et al., 1999; Kasten, 2003; Grabowska et al., 2014).

However, this pattern is observed only after intensive flooding. Our research indicates that changes in environmental conditions and the resultant shifts in the biocenosis are closely related to the water inflow rate. Rapid and abundant flooding can significantly affect the structure of plankton communities in oxbow lakes, as was seen during and after the flood of the Vistula River in 2010 
(Napiórkowski and Napiórkowska, 2014). However, the majority of our observations were taken when the water inflow rate was low. We did not notice considerable changes in the oxbow.

Water transparency in limnophase and potamophase did not differ significantly. Similarly, only small differences were recorded between the average values of several physical and chemical parameters including $\mathrm{DO}, \mathrm{pH}$ and EC. It must be noted, however, that during potamophase, water in the Vistula river, characterized by a stable oxygen regime (Glińska-Lewczuk and Burandt, 2011), improved the saturation of the oxbow.

Our observations indicate that a small supply of water during potamophase enriched the oxbow with new zooplankton species (mainly rotifers) and increased the biodiversity index $\left(H^{\prime}\right)$. Seventeen new species were introduced into the oxbow with river water, while at the same time, species typical of limnophase were not destroyed. According to the intermediate disturbance hypothesis (IDH), a small inflow of river water can stimulate the development of a variety of zooplankton species (Connel, 1978).

The IDH (Connel, 1978) predicts low species diversity in habitats exposed to high levels of disturbance, where only a small number of highly tolerant species can survive or rapidly recolonize (Napiórkowski and Napiórkowska, 2014; Joniak and Kuczyńska-Kippen, 2016). According to this hypothesis, low species diversity also occurs under very low levels of disturbance, where highly competitive species can monopolize resources. With intermediate perturbation, species diversity is the highest because a variety of taxa can tolerate the conditions, but none can completely dominate the community (Ward et al., 1999).

According to the IDH, the highest biodiversity index $H^{\prime}$ and the highest number of species were recorded during potamophase, at a moderate, constant river inflow. During the isolation, the lack of water supply guaranteed no disturbances in the oxbow, which led to greater zooplankton density with the dominance of few species. Increased zooplankton density was accompanied by a lower number of species and a lower zooplankton biodiversity index $H^{\prime}$. Similarly to the oxbows of the Danube (Schöll, 2010), as stated by IDH (Connel, 1978), we observed the highest biodiversity where weak but constant current was noted.

Although more species were identified during potamophase, the same species were dominant in both phases. However, their contribution was different. Rotifers, accounting for nearly $90 \%$ of all organisms, predominate in the zooplankton of the investigated oxbow lake.

It has been suggested that the apparent predominance of rotifers in rivers and oxbow lakes may be connected with their small size and relatively short generation time compared with larger crustaceans (van Dijk and van Zanten, 1995; Radwan et al., 2004; Lair, 2006). In addition, rotifers appear to be better adapted to adverse conditions of lotic and semi-lotic habitats (Marneffe et al., 1996; Wilk-Woźniak et al., 2014).

Despite a small river inflow into the lake, we noted a negative impact of a higher WL (potamophase) on the number of species and density of the crustacean zooplankton $(r=-0.373 ; r=-0.585 P \leq 0.05)$ (Table 4, Fig. 2).

Temperature, one of the most important physical parameters determining biological processes in the aquatic environment (de Azevedo and Bonecker, 2003; Vadadi-Fülöp et al., 2009), played an important role during limnophase. With no water inflow from the river, water temperature in the oxbow increased, thus increasing the number of species and density of crustaceans. Higher temperature promoted the growth of Cladocera (Forro et al., 2008). Temperature was positively correlated with both the number of crustacean species and their density $(r=0.566 ; r=0.374 P \leq 0.05)$ (Table 4).

Elevated water temperature in the oxbow during limnophase increases biomass of small algae (diatoms) (Dembowska, 2015a; Dembowska and Napiórkowski, 2015), a good source of food for zooplankton (Kosiba et al., 2017). This increases the density of rotifers (a two-fold increase) and crustaceans (an almost three-fold increase). In addition, the density of dominant organisms is higher during limnophase. Our results confirm these observations (Table 3).

CCA analysis confirmed a higher diversity index $H^{\prime}$ and a higher number of rotifer species and zooplankton species at a higher WL (potamophase). At a lower WL (limnophase), it was the temperature (WT) that affected the number of crustacean species and their density (Fig. 3).

\section{Conclusions}

During potamophase, the inflow of water from the river to an oxbow lake may lead to an increased number of species and a higher biodiversity index $\left(H^{\prime}\right)$ according to IDH.

The isolation of oxbow lakes during limnophase leads to increases in their water temperature. This accelerates the growth of phytoplankton (increased biomass) and zooplankton (increased density of zooplankton including rotifers and crustaceans, and increased number of crustacean species).

However, even slightly increased WLs may result in a decreased density of crustaceans and a lower number of crustacean species during potamophase.

Moreover, even small changes in river hydrology may affect environmental conditions in oxbow lakes, thus affecting zooplankton populations.

In recent years, probably due to climate change, the amount of precipitation has diminished. As a result, WLs in rivers are low and potamophase is rare, causing oxbows to remain isolated and to have low WLs. This increases primary productivity and reduces biodiversity not only in 


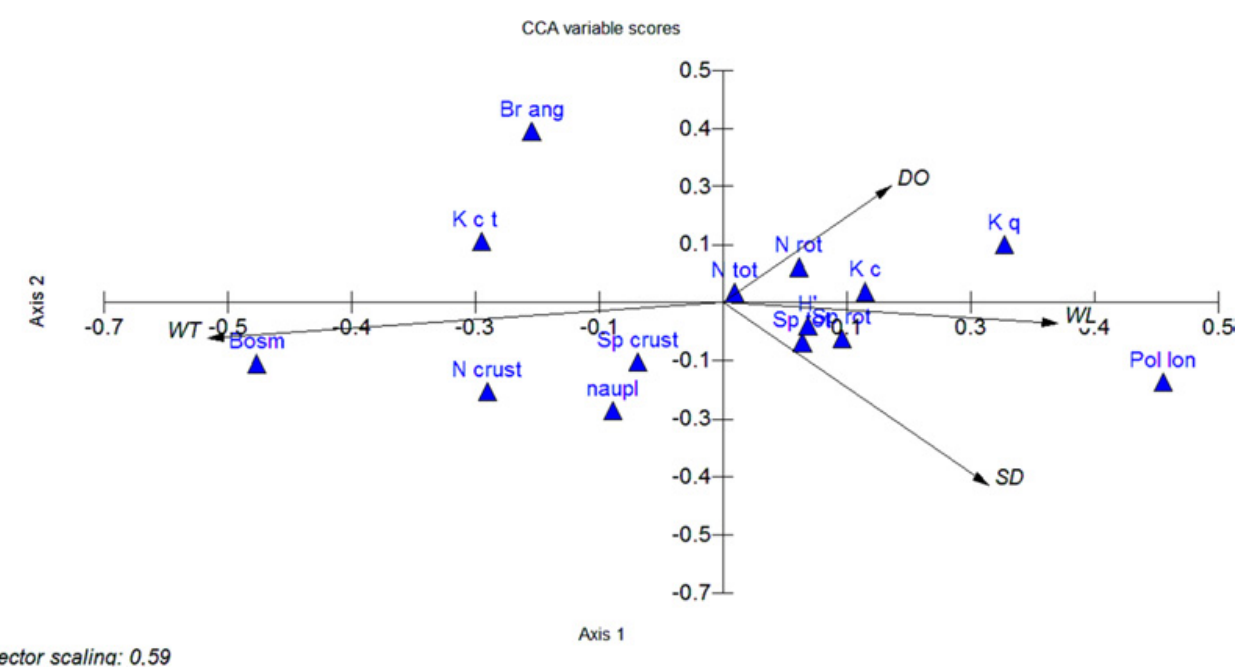

Fig. 3. Canonical correspondence analysis (CCA) analysis of zooplankton data ( $\mathrm{Sp}_{\mathrm{tot}}-$ total zooplankton species number, $\mathrm{Sp}_{\text {rot }}$ - rotifers species number, $\mathrm{Sp}_{\text {crust }}-$ crustacean species number, $\mathrm{N}_{\text {tot }}$ - total zooplankton abundance, $\mathrm{N}_{\text {rot }}-$ rotifers abundance, $\mathrm{N}_{\text {crust }}$ - crustacean abundance, $H^{\prime}$ - Shannon biodiversity index, Kct - Keratella tecta abundance, Kc - Keratella cochlearis abundance, $\mathrm{Kq}$ - Keratella quadrata abundance, Pol long - Polyarthra longiremis abundance, Br ang - Brachionus angularis abundance, Bosm - Bosmina longirostris abundance, naupl - nauplii abundance) and environmental variables (WT - water temperature, DO - oxygen concentration, WL - water level, SD - transparency).

oxbows but also in entire river valleys. For this reason, measures need to be taken to protect these extremely valuable ecosystems.

\section{References}

Amorus C. and Bornette G., 2002. Connectivity and biocomplexity in waterbodies of riverine floodplains. Freshwater Biol., 47, 761-776.

Anderson S.M.A. and Bonecker C.C., 2004. Rotifers in different environments of the Upper Parana river floodplain (Brazil): richness, abundance and the relationship with connectivity. Hydrobiologia, 522, 281-290. doi: 10.1023/ B:HYDR.0000029980.48859.40.

Baranyi Ch., Hein T., Holarek C., Keckeis S. and Schiemer F., 2002. Zooplankton biomass and community structure in a Danube River floodplain system: effects of hydrology. Freshwater Biol., 47, 473-482. doi: 10.1046/j.13652427.2002.00822.x.

Carvalho P.L.M., Bini S.M., Thomaz L.G., Oliveira B., Robertson W.L.G., Tavechio W.L. and Darwisch A.J., 2001. Comparative limnology of South-American lakes and lagoons. Acta Scientiarum, 23, 265-273.

Chaparro G., Marinone M.C., Lombardo R.J., Schiaffino M.R., de Souza Guimarães A. and O'Farrell I., 2011. Zooplankton succession during extraordinary droughtflood cycles: a case study in South American floodplain lake. Limnologica, 41, 371-381. doi: 10.1016/j.limno. 2011.04.003.

Chaparro G., Fontanarrosa M.S. and O'Farrel I., 2015. Colonization and succession of zooplankton after a drought: influence of hydrology and free-floating plant dynamics in a floodplain lake. Wetlands, 36, 85-100. doi: 10.1007/ s13157-015-0718-3.
Connel J.H., 1978. Diversity in tropical rain forest and coral reefs. Science, 199, 1302-1310.

de Azevedo F. and Bonecker C.C., 2003. Community size structure of zooplanktonic assemblages in three lakes on the upper River Paraná floodplain, PR-MS, Brazil. Hydrobiologia, 505, 147-158. doi: 10.1023/ B:HYDR.0000007303.78761.66.

Dembowska E.A., 2015a. Seasonal variation in phytoplankton and aquatic plants in floodplain lakes (lower Vistula River, Poland). Wetl. Ecol. Manag., 23, 535-549. doi: 10.1007/ s11273-015-9408-4.

Dembowska E.A., 2015b. Changes of phytoplankton in oxbow lake with lower Vistula River. XXIII Congress of Polish Hydrobiologists [Zjazd Hydrobiologów Polskich], Koszalin 2015, Materials, 58.

Dembowska E.A. and Napiórkowski P., 2012. Why do we have to protect old river beds? [Dlaczego musimy chronić starorzecza. Kosmos, Problemy Nauk Biologicznych, 61, 341-349. Polish (abstract in English).

Dembowska E.A. and Napiórkowski P., 2015. A case study of the planktonic communities in two hydrologically different oxbow lakes, Vistula River, Central Poland. J. Limnol., 74, 346-357. doi: 10.4081/jlimnol.2014.1057.

de Paggi S.B.J. and Paggi J.C., 2008. Hydrological connectivity as shaping force in the zooplankton community of two lakes in the Parana River Floodplain. Int. Rev. Hydrobiol., 93, 659-678. doi: 10.1002/iroh.200711027.

Einsle U., 1996. Copepoda: Cyclopoida - genera Cyclops, Megacyclops, Acanthocyclops. In: Dumont H.J. (ed.), Guides to the Identification of the Microinvertebrates of the Continental Waters of the World 10, SPB Acad. Publ. bv., $82 \mathrm{p}$.

Flössner D., 1972. Die tierwelt Deutschlands. 60 teil. Krebstiere, Crustacea. Kiemen und Blattfüsser, Branchiopoda FischläuseBranchiura, VEB Gustav Fischer Verlag, Jena, German, 380 p. 
Forro L., Korovchinsky N.M., Kotov A.A. and Petrusek A., 2008. Global diversity of cladocerans (Cladocera; Crustacea) in freshwater. Hydrobiologia, 595, 177-184. doi: 10.1007/ s10750-007-9013-5.

Funk A., Reckendorfer W., Kucera-Hirzinger V., Raab R. and Schiemer F., 2009. Aquatic diversity in a former floodplain: remediation in an urban context. Ecol. Eng., 35, 1476-1484. doi: 10.1016/j.ecoeng.2009.06.013.

Furst D.J., Aldridge K.T., Shiel R.J., Ganf G.G., Mills S. and Brookes J.D., 2014. Floodplain connectivity facilitates significant export of zooplankton to the main River Murray channel during a flood event. Inland Waters, 4, 413-424. doi: 10.5268/IW-4.4.696.

Glińska-Lewczuk K. and Burandt P., 2011. Effect of river straightening on the hydrochemical properties of floodplain lakes: observations from the Łyna and Drwęca Rivers, N Poland. Ecol. Eng., 37, 786-795. doi: 10.1016/ j.ecoleng.2010.07.028.

Grabowska M., Glińska-Lewczuk K., Obolewski K., Burandt P., Kobus S., Dunalska J., Kujawa R., Goździejewska A. and Skrzypczak A., 2014. Effects of hydrological and physicochemical factors on phytoplankton communities in floodplain lakes. Pol. J. Environ. Stud., 23, 713-725.

Gumiri S., Ardianor L., Wulandari L., Buchar T. and Iwakuma T., 2005. Seasonal dynamics of zooplankton communities in interconnected tropical swamp lake ecosystem. Vehr. Int. Verein. Theor. Angew. Limnol., 29, 179-184.

Harris R.P., Wiebe P.H., Lenz J., Skjoldal H.R. and Huntley M., 2000. Zooplankton Methodology Manual, ICES Academic Press, 147-173.

Hein T., Heiler G., Pennetzdorfer D., Riedler P., Schagerl M. and Schimer F., 1999. The Danube restoration project: functional aspects and planktonic productivity in the floodplain system. Regul. Rivers Res. Manage., 15, 259-270. doi: $\quad$ 10.1002/(SICI)1099-1646(199901/06)15:1/3<259: AID-RRR539 > 3.0.CO;2-E.

Hillbricht-Ilkowska A., 1999. Shallow lakes in lowland river systems: role in transport and transformations of nutrients and in biological diversity. Hydrobiologia, 408/409, 349-358.

IBM Corp. Released, 2012. IBM SPSS Statistic for Windows Version 21.0, IBM Corp, Armonk, NY.

Joniak T. and Kuczyńska-Kippen N., 2016. Habitat features and zooplankton community structure of oxbows in the limnophase: reference to transitional phase between flooding and stabilization. Limnetica, 35, 37-48.

Junk W.J., Bayley P.B. and Sparks R.E., 1989. The flood pulse concept in river-floodplain systems. In: D.P. Dodge [ed.] Proceedings of the International Large River Symposium. Can. Spec. Publ. Fish Aquat. Sci., 106, 110-127.

Kasten J., 2003. Inundation and isolation: dynamics of phytoplankton communities in seasonal inundated flood plain waters of the Lower Odra Valley National Park - Northeast Germany. Limnologica, 33, 99-111.

Keckeis S., Baranyi Ch., Hein T., Holarek C., Riedler P. and Schiemer F., 2003. The significance of zooplankton grazing in a floodplain system of the River Danube. J. Plankton Res., 25, 243-253. doi: 10.1093/plankt/25.3.243.

Kentzer A., Dembowska E., Giziński A. and Napiórkowski P., 2010. Influence of the Włocławek Reservoir on hydrochemistry and plankton of a large, lowland river (the Lower Vistula River, Poland). Ecol. Eng., 36, 1747-1753. doi: 10.1016/j.ecoleng.2010.07.024.
Kiefer F., 1978. Freilebende Copepoda. In: Kiefer F. and Fryer G. (eds.), Das zooplankton der Binnengewässer. 2, Teil, Stuttgart, German, 250 p.

Kobayashi T., Ralph T.J., Ryder D.S., Hunter S.J., Shiel R.J. and Segers H., 2015. Spatial dissimilarities in plankton structure and function during flood pulses in a semi-arid floodplain wetland system. Hydrobiologia, 747, 19-31. doi: 10.1007/s10750-014-2119-7.

Kosiba J., Wilk-Woźniak E., Krztoń W., Strzesak M., Pociecha A., Walusiak E., Pudaś K. and Szarek-Gwiazda E., 2017. What underpins the trophic networks of the plankton in shallow oxbow lakes. Microb. Ecol., 73, 17-28. doi: 10.1007/s00248-016-0833-6.

Kovach W.L., 2010. MVSP - A MultiVariate Statistical Package for Windows, ver. 3.2 Kovach Computing Services, Pentraeth, Wales, UK.

Krztoń W., Pudaś K., Pociecha A., Strzesak M., Kosiba J., Walusiak E., Szarek-Gwiazda E. and Wilk-Woźniak E., 2017. Microcystins affect zooplankton biodiversity in oxbow lakes. Environ. Toxicol. Chem., 36, 165-174. doi: 10.1002/ etc.3519.

Lair N., 2006. Abiotic vs. biotic factors: lessons drawn from rotifers in the Middle Loire a meandering river monitored from 1995 to 2002, during low flow periods. Hydrobiologia, 546, 457-472. doi: 10.1007/s10750-005-4289-9.

Lake P.S. and Bond N.R., 2007. Australian futures: freshwater ecosystems and human water usage. Future, 39, 288-305.

Makowski J., 1998. The lower Vistula River and its bunds. The historical development and the current state and maintenance during major floods. Part Two: The section from Toruń to Biała Góra. Instytut Budownictwa Wodnego PAN Biblioteka Naukowa Hydrotechnika 27. Polish, 150 p.

Marneffe Y., Descy J.P. and Thome J.P., 1996. The zooplankton of the lower river Meuse, Belgium: seasonal changes and impact of industrial and municipal discharges. Hydrobiologia, 319, 1-13.

Mihaljević M., Stević F., Horvatić J. and HackenbergerKutuzović B., 2009. Dual impact of the flood pulses on the phytoplankton assemblages in a Danubian floodplain lake (Kopački Rit Nature Park, Croatia). Hydrobiologia, 618, 77-88. doi: 10.1007/s00248-012-0016-z.

Napiórkowski P., 2009. Influence of hydrological conditions on zooplankton of oxbow lakes (old riverbeds) of the Lower Vistula in the city of Toruń. Limnol. Pap., 4, 55-67. doi: 10.2478/v10232-011-0027-7.

Napiórkowski P. and Napiórkowska T., 2014. The impact of catastrophic flooding on zooplankton. Pol. J. Environ. Stud., 23, 409-417.

Neiff J.J., 1996. Large rivers of South America: toward the new approach. Verh. Internat. Verein. Limnol., 26, 167-180.

Nogrady T., Wallance R.L. and Snell T.W., 1993. Rotifera, biology, ecology and systematic - vol. 4. In: Dumont H.J. (ed.), Guides to the Identification of the Microinvertebrates of the Continental Waters of the World, SPB Acad. Publ., $142 \mathrm{p}$.

Paidere J., 2009. Influence of flooding frequency on zooplankton in the floodplains of the Daugava River (Latvia). Acta Zoologica Lituanica, 19, 306-313. doi: 10.2478/v10043-0090036-1.

Paira A.R. and Drago E.C., 2007. Origin, evolution and types of floodplain water bodies. In: Iriondo M.H., Paggi J.C. and Parma M.J. (eds.), The Middle Paraná River: Limnology of 
Subtropical Wetlands, Springer-Verlag, Berlin, Heidelberg, 53-80.

Radwan S., Bielańska-Grajner I. and Ejsmont-Karabin J., 2004. Rotifers (Rotifera), Freshwater fauna of Poland. 32, Oficyna Wydawnicza Tercja, Łódź (in Polish), 447 p.

Reckendorfer W., Funk A., Gschöpf Ch., Hein T. and Schimer F., 2013. Aquatic ecosystems functions of an isolated floodplain and their implications for flood retention and management. J. Appl. Ecol., 50, 119-128. doi: 10.1111/ 1365-2664.12029.

Redford K.H. and Richter B.D., 1999. Conservation of biodiversity in a world of use. Conserv. Biol., 13, 1246-1256. doi: 10.1046/j.1523-1739.1999.97463.x.

Riss T. and Biggs B.J.F., 2003. Hydrologic and hydraulic control of macrophyte establishment and performance in streams. Limnol. Oceanogr., 48, 1488-1497.

Rybak J.I. and Błędzki L.A., 2010. Freshwater Planktonic Crustacea. Key for Species Identification. [Słodkowodne skorupiaki planktonowe. Klucz do oznaczania gatunków] (in Polish), Warsaw University Press, Warsaw, 366 p.

Scheffer M. and Jeppesen E., 1998. Alternative stable state. In: Scheffer M. (ed.), Ecology of Shallow Lakes, Chapman and Hall, London, $357 \mathrm{p}$.

Scheffer M., Hosper S.H., Meijer M.L., Moss B. and Jeppesen E., 1993. Alternative equilibria in shallow lakes. Trends Ecol. Evol., 8, 275-279.

Schöll K., 2009. Diversity of planktonic rotifer assemblages in the water bodies of the Gemenc floodplain (Duna-Drava National Park, Hungary). Biol. B, 64, 951-958. doi: 10.2478/ s11756-009-0153-0.

Schöll K., 2010. Spatial and temporal diversity patterns of planktonic rotifer assemblages in water bodies of floodplain Gemenc (Duna-Dráva National Park, Hungary).
Internat. Rev. Hydrobiol., 95, 450-460. doi: 10.1002/ iroh.201011281.

Shiel R.J., Green J.D. and Nielsen D.L., 1998. Floodplain biodiversity: why are there so many species? Hydrobiologia, 387/388, 39-46.

Smirnov N.N., 1996. Cladocera: the Chydoridae and Sayciinae (Chydoridae) of the World. In: Dumont H.J. (ed.), Guides to the Identification of the Microinvertebrates of the Continental Waters of the World, SPB Acad. Publ. bv., 143 p.

Thomaz S.M., Bini L.M. and Bozelli R.L., 2007. Floods increase similarity among aquatic habitats in river-floodplain systems. Hydrobiologia, 579, 1-13. doi: 10.1007/s10750-006-0285-y.

Tockner K., Robinson Ch.T. and Uehlinger U.R.S., 2009. Rivers of Europe, AP Elsevier, 700 p.

Vadadi-Fülöp Cs., Hufnagel L., Jablonszky G. and Zsuga K., 2009. Crustacean plankton abundance in the Danube River and its side arms in Hungary. Biologia, 64/6, 1184-1195. doi: 10.2478/s11756-009-0202-8.

van Dijk G.M. and van Zanten B., 1995. Seasonal changes in zooplankton abundance in the lower Rhine during 1987-1991. Hydrobiologia, 304, 29-38.

Ward J.V., Tockner K. and Schimer F., 1999. Biodiversity of floodplain river ecosystems: ecotones and connectivity. Regul. Rivers Res. Mgmt., 15, 125-139.

Wilk-Woźniak E., Pociecha A., Amirowicz A., Gąsiorowski M. and Gadzinowska J., 2014. Do planktonic rotifers rely on terrestrial organic matter as a food source in reservoir ecosystems? Int. Rev. Hydrobiol., 99, 157-160. doi: 10.1002/ iroh.201301717.

Wojciechowska W., Pasztaleniec A. and Solis M., 2007. Diversity and dynamics of phytoplankton in floodplain lakes (River Bug, eastern Poland). Oceanol. Hydrobiol. St., 36 (Suppl. 1), 199-208. 